\title{
PELATIHAN KEWIRAUSAHAAN BAGI PELAKU UMKM DAN MASYARAKAT DI KELURAHAN SUKARAME BANDAR LAMPUNG
}

\author{
Rahyono $^{1}$, Apip Alansori ${ }^{2}$ \\ ${ }^{1,2)}$ Program Studi Manajemen, Fakultas Ekonomi, Universitas Malahayati \\ e-mail: Rahyono@Malahayati.ac.id, apipalansori95@gmail.com
}

\begin{abstract}
Abstrak
Dalam era globalisasi sekarang ini tingkat persaingan semakin tinggi baik dalam mencari pekerja maupun dalam mencari peluang pendapatan. Oleh karena itu kita tidak bisa tergantung kepada pemerintah, tapi hendaknya ada keinginan untuk berwirausaha. Permasalahan pada umumnya yang menjadi pikiran pelaku usaha tersebut yang menghambat pertumbuhannya meliputi beberapa hal mendasar seperti; lemahnya mental berwirausaha, ketertutupan dan ketidakjelasan entitas, akuntabilitas, pemasaran, keterikatan yang kuat pada tradisi sehingga kurang tanggap dan adaptif terhadap tuntutan perubahan, ketertinggalan tekhnologi, dan cenderung mengabaikan mutu. Permasalahan ini mencuat kepermukaan sejalan dengan kondisi lingkungan bisnis yang semakin kompleks dan penuh ketidakpastian pada akhir-akhir ini dan ke depan. Oleh karena itu perlu diupayakan program berkelanjutan untuk menumbuhkan mentalitas dan budaya bisnis, kreativitas disain produk, penyerapan kemajuan tekhnologi, serta pengetahuan dan ketrampilan manajerial yang sesuai dengan tuntutan lingkungan bisnis yang terus berubah. Tujuan kegiatan pengabdian kepada masyarakat ini adalah untuk memberikan pelatihan tentang kewirausahaan kepada pelaku usaha dan masyarakat agar bisa menjalanakan usahanya dan mampu untuk bersaing supaya bisa mencapai kesejahteraan. Dari hasil pelaksanaan Pengabdian Kepada Masyarakat, peserta pelatihan merespon secara positif dan terlihat puas. Dapat terlihat pula antusiasme peserta untuk menjadi wirausaha yang ditunjukkan dengan keaktifan berpartisipasi dalam pelatihan. Peserta juga telah menunjukkan pemahaman mereka tentang kewirausahaan dan pemasaran yang didukung dengan berhasilnya mereka mempraktikkan secara mandiri proses pemasaran yang telah diajarkan.
\end{abstract}

Kata kunci: Pelatihan, Kewirausahaan, Pelaku UMKM

\begin{abstract}
In the current era of globalization, the level of competition is getting higher both in looking for workers and in looking for income opportunities. Therefore, we cannot depend on the government, but there should be a desire to become entrepreneurs. Problems in general that become the mind of the business actor that hinders their growth include several basic matters such as; weak entrepreneurial mentality, closeness and unclear entity, accountability, marketing, strong attachment to tradition so that it is less responsive and adaptive to the demands of change, is behind technology, and tends to ignore quality. This problem has been sticking out on the surface in line with the increasingly complex and uncertain business environment in recent times and in the future. Therefore, it is necessary to strive for sustainable programs to foster business mentality and culture, creativity in product design, absorption of technological advances, as well as managerial knowledge and skills that are in line with the demands of the ever-changing business environment. The purpose of this community service activity is to provide training on entrepreneurship to entrepreneurs and the community so that they can run their business and be able to compete in order to achieve prosperity. From the results of the implementation of Community Service, the training participants responded positively and looked satisfied. It can also be seen that the enthusiasm of the participants to become entrepreneurs is shown by actively participating in the training. Participants have also demonstrated their understanding of entrepreneurship and marketing which is supported by their success in independently practicing the marketing process that has been taught.
\end{abstract}

Keywords: Training, Entrepreneurship, MSME Actors. 


\section{PENDAHULUAN}

Dalam era globalisasi sekarang ini tingkat persaingan semakin tinggi baik dalam mencari pekerja maupun dalam mencari peluang pendapatan.Oleh karena itu kita tidak bisa tergantung kepada pemerintah, tapi hendaknya ada keinginan untuk berwirausaha. Salah satu cara berwirausaha adalah terlebih dahulu kita harus mempunyai jiwa berwirausaha dan mempunyai motivasi untuk berwirausaha, oleh karena itu perlu adanya pelatihan berwirausaha ini. Pembinaan dan pengembangan usaha dengan menunbuhkan jiwa wirausaha dan meningkatkan kemampuan berusaha ke depan, haruslah dilakukan dengan penataan ulang segala aspek, kebijakan dan prosedur dari sistem yang telah diterapkan selama ini baik secara nasional maupun regional dan lokal. Berbagai komplikasi kebijakan dan prosedur serta program yang ada harus dipangkas. Bidang usaha difokuskan pada penciptaan produk dan jasa yang diminta pasar baik pasar input maupun pasar output dengan mengandalkan keunggulan kompetitif (Susita et all, 2017).

Salah satu cara untuk meningkatkan jumlah usaha adalah dengan meningkatkan sektor kewirausahaan, sehingga muncul pengusaha-pengusaha baru yang potensial dan handal. Kewirausahaan adalah suatu tindakan kreatif dalam memanfaatkan kesempatan untuk mengawaili dan menjalankan suatu kegiatan tertentu dengan tujuan memberikan pelayanan terbaik kepada pelanggan dan pihak lain. Menjadi wirausaha berarti memiliki kemampuan menemukan dan mengevaluasi peluang-peluang, mengumpulkan sumberdaya yang diperlukan dan bertindak untuk mendapatkan keuntungan dari peluang tersebut. Kewirausahaan merupakan kombinasi dari karakter wirausaha, kesempatan, dukungan sumber daya dan tindakan (Rumawas, 2018).

Saat ini peluang untuk memulai langkah sebagai wirausaha sudah sangat terbuka. Pemerintah maupun perbankan pun telah mendukung para wirausahawan dan wirausahawati melalui pemberian akses keuangan. Akses tersebut diharapkan dapat memberi kesempatan bagi para wirausaha dalam mengembangkan kegiatan usaha mereka (Aryani et all, 2020).

Permasalahan pada umumnya yang menjadi pikiran pelaku usaha tersebut yang menghambat pertumbuhannya meliputi beberapa hal mendasar seperti; lemahnya mental berwirausaha, ketertutupan dan ketidakjelasan entitas, akuntabilitas, pemasaran, keterikatan yang kuat pada tradisi sehingga kurang tanggap dan adaptif terhadap tuntutan perubahan, ketertinggalan tehnologi, dan cenderung mengabaikan mutu. Permasalahan ini mencuat kepermukaan sejalan dengan kondisi lingkungan bisnis yang semakin kompleks dan penuh ketidakpastian pada akhir-akhir ini dan ke depan. Oleh karena itu perlu diupayakan program berkelanjutan untuk menumbuhkan mentalitas dan budaya bisnis, kreativitas disain produk, penyerapan kemajuan tekhnologi, serta pengetahuan dan ketrampilan manajerial yang sesuai dengan tuntutan lingkungan bisnis yang terus berubah (Farid et all, 2020).

Kondisi UMKM yang ada di Kelurahan Sukarame adalah sebagai berikut:

1. Pelaku UMKM berasal dari berbagai jenis usaha.

2. Mereka belum memahami konsep kewirausahaan, segmentasi komsumen, dan pengembangan produk.

3. Sebagian besar memasarkan produknya ke pasar tradisional atau menunggu konsumen datang ke rumahnya.

4. Beberapa pelaku UMKM telah memasarkan produknya melalui media sosial, namun belum menjalankan secara optimal.

Penumbuhan jiwa kewirausahaan juga mampu memberikan manfaat bagi masyarakat. Manfaaat tersebut dapat berujud manfaat finansial maupun non finansial. Manfaat finansial dari kewirausahaan dapat berupa kemandirian ekonomi yang diperoleh dalam menjalankan usaha. Sedangkan manfaat non finansial berupa penumbuhan mental yang tangguh dan pantang menyerah dalam menghadapai permasalahan hidup. Berdasarkan uraian yang telah dijelaskan sebelumnya, perlu diadakan pelatihan kewirausahaan bagi masyarakat khususnya genarasi muda untuk menumbuhkan jiwa kewirausahaan dan menggali potensi yang ada. Dengan diadakan pelatihan kewirausahaan diharapkan mampu memunculkan usaha baru dan memberikan efek positif pada pengembangan mental kemandirian generasi muda (Ismail et all, 2020).

Dalam kegiatan pelaksanaan Pengabdian Masyarakat kali ini, para dosen di Program Studi S1 Manajemen Fakultas Ekonomi Universitas Malahayati Bandar Lampung merasa tertarik untuk melakukan pelatihan kewirausahaan bagi para pelaku UMKM dan masyarakat, sekaligus 
memberikan motivasi agar usaha yang sedang dikembangkan dapat terus bertahan serta berdaya saing di tengah persaingan yang begitu ketat.

Tujuan kegiatan pengabdian kepada masyarakat ini adalah untuk memberikan pelatihan tentang kewirausahaan kepada pelaku usaha dan masyarakat agar bisa menjalanakan usahanya dan mampu untuk bersaing supaya bisa mencapai kesejahteraan. Manfaat dari kegiatan ini bagi mitra pengabdian adalah memberikan pengetahuan tentang cara bagaimana menjadi wirausaha yang mampu bersaing meskipun kondisi ekonomi belum stabil agar bisa memenuhi kebutuhan hidup. Setelah mengikuti pelatihan ini, semua peserta akan dapat termotivasi, disiplin dan komitmen untuk mmenjalankan usahanya serta kesadaran para pelaku usaha dalam meningkatkan pendapatan. Tim pengabdi melaksanakan pelatihan kewirausahaan yang dapat langsung diaplikasikan oleh mitra untuk meningkatkan pengetahuan dan keterampilan dalam berwirausaha serta berdampak pada peningkatan produktivitas dan kesejahteraannya.

Berdasarkan permasalahan yang diuraikan diatas maka solusi yang di tawarkan adalah dalam bentuk pelatihan kewirausahaan. Pelatihan kewirausahaan dalam bentuk teori maupun praktek. Dalam materi pelatihan ini peserta akan memperoleh pengetahuan teori dan praktek kewirausahaan. Berikut cakupan materi pelatihan kewirausahaan:

1. Membangun Jiwa Kewirausahaan

Materi ini peserta akan dibekali tentang berbagai trik, cara, strategi membangun jiwa kewirausahaan.

2. Mengenal Konsep Dasar Kewirausahaan

Materi ini peserta akan dibekali tentang seluk beluk wirausaha. Apa, mengapa dan bagaimana berwirausaha merupakan konsep dasar yang harus difahamkan kepada peserta.

3. Manajemen Usaha Kecil

Bagian ini peserta dijelaskan tentang aspek pemasaran, aspek produksi, aspek pemodalan dan keuangan, dan aspek sumber daya manusia.

4. Legalitas Usaha

Peserta dijelaskan mengenai bentuk-bentuk badan usaha baik usaha formal maupun informal.

5. Perencanaan Usaha

Peserta diperkenalkan dan sekaligus dilatih untuk mengenal peluang usaha, bagaimana menemukannya, bagaimana memilihnya, dan bagaimana memulainya.

\section{METODE}

Metode yang digunakan dalam melaksanakan kegiatan ini adalah dengan melakukan diskusi pelatihan dan koordinasi terlebih dahulu kepada Lurah sebagai penangungjawab mitra yang dilanjutkan dengan rapat terkait pelaksanaan dan sasaran masyarakat di wilayah setempat. Pelaksanaan pada awalnya peserta pelatihan diberikan pemahaman tentang manfaat dan pentingnya berwirausaha untuk kemajuan usaha dan kesejahteraan. Metode yang digunakan dalam pelaksanaan kegiatan pengabdian kepada masyarakat adalah pelatihan dengan cara:

1. Memberikan pelatihan kepada Pelaku UMKM dan masyarakat tentang kewirausahaan.

2. Memberikan pendampingan dalam pemasaran dan mempromosikan produk UMKM.

3. Pemahaman konsep kewirausahaan, metode digunakan adalah ceramah, diskusi, dan tanya jawab.

4. Menuangkan rencana bisnis ke dalam bisnis model kanvas, metode yang digunakan adalah ceramah, demonstrasi, diskusi, tanya jawab, dan pendampingan mitra.

5. Kemampuan memasarkan produk dengan memanfaatkan media sosial, maka metode yang digunakan adalah ceramah, demonstrasi, diskusi, tanya jawab, dan pendampingan mitra.

Prosedur kerja yang mencakup kegiatan dan indikator pengukuran keberhasilan dapat dilihat pada tabel 1. 
Tabel 1.

Prosedur Kerja

\begin{tabular}{clll}
\hline Tahapan & \multicolumn{1}{c}{ Kegiatan } & \multicolumn{3}{c}{ Indikator } \\
\hline 1 & $\begin{array}{l}\text { Pelatihan dan diskusi tentang } \\
\text { kewirausahaan }\end{array}$ & $\begin{array}{l}\text { Menilai pemahaman tentang kewirausahaan } \\
\text { melalui diskusi Tanya jawab. }\end{array}$ & $\begin{array}{c}\text { Peningkatkan jumlah penjualan } \\
\text { usaha }\end{array}$ \\
\hline 2 & $\begin{array}{l}\text { Pendampingan terhadap pelaku } \\
\text { pendapatan }\end{array}$ & \begin{tabular}{l} 
Menan \\
\hline
\end{tabular}
\end{tabular}

Pelaksanaan kegiatan PKM dilakukan dengan tahapan sebagai berikut:

1. Pada tahap awal mitra memberikan perizinan untuk melaksanakan kegiatan pengabdian masyarakat dengan menandatangani perizinan program pelatihan kewirausahan dan pemasaran.

2. Pada tahap pelaksanaan, mitra berpartisipasi dalam menyediakan sarana dan tempat pelaksanaan.

3. Pengusul melaksanakan pelatihan kewirausahaan dan pendampingan, menyiapkan materi dan bahan/alat untuk menunjang kegiatan yang akan dilakukan.

Kegiatan Pengabdian Kepada Masyarakat dengan tema Pelatihan Kewirausahaan bagi UMKM dan Masyarakat di Kelurahan Sukarame Bandar Lampung telah dilaksanakan pada tanggal 25 Agustus 2020 di Kantor Kelurahan Sukarame. Setelah pelatihan dilakukan, pendampingan tetap diberikan selama 2 minggu.

\section{HASIL DAN PEMBAHASAN}

Sesuai dengan rencana yang telah ditentukan sebelum kegiatan pealtihan dilaksanakan, kegiatan pengabdian kepada masyarakat ini diawali dengan kegiatan administratif berupa perijinan, dan undangan peserta. Peserta pelatihan ini merupakan pelaku UMKM dan masyarakat yang ada di Kelurahan Sukarame Bandar Lampung. Kegiatan pengabdian masyarakat ini diselenggarakan oleh universitas Malahayati dan bekerjasama dengan Kelurahan Bandar Lampung . Peserta dalam kegiatan ini adalah pelaku usaha yang berada dilingkungan Kelurahan dan mewakili dari RT selama 1 hari.

Dari hasil pelaksanaan Pengabdian Kepada Masyarakat, peserta pelatihan merespon secara positif dan terlihat puas. Dapat terlihat pula antusiasme peserta untuk menjadi wirausaha yang ditunjukkan dengan keaktifan berpartisipasi dalam pelatihan. Peserta juga telah menunjukkan pemahaman mereka tentang kewirausahaan dan pemasaran yang didukung dengan berhasilnya mereka mempraktikkan secara mandiri proses pemasaran yang telah diajarkan. Setelah kegiatan Pengabdian kepada masyarakat dilaksanakan, tim memantau kegiatan peserta, terutama yang berminat untuk menjadikan kegiatan ini sebagai usaha untuk meningkatkan usaha yang sudah mereka jalankan atau bagi yang baru akan memulai usaha. Tim juga siap membantu kelompok untuk meningkatkan kualitas usahanya, khususnya dalam hal strategi pemasaran, pengemasan produk, penetapan harga, dan lain-lain supaya minat konsumen terhadap produk ini semakin tinggi dan juga agar jiwa berwirausaha menjadi semakin meningkat.

Dalam pelatihan kewirausahaan ini mitra mendapatkan materi yaitu, pertama Membangun jiwa kewirausahaan, pada materi ini peserta akan dibekali tentang berbagai trik, cara dan strategi membangun jiwa kewirausahaan. Kedua, mengenal konsep dasar kewirausahaan, pada bagian ini peserta akan dibekali tentang seluk-beluk wirausaha. Apa, mengapa dan bagaimana berwirausaha yang adalah konsep dasar yang harus dipahami. Ketiga, manajemen usaha kecil, pada bagian ini peserta dijelaskan mengenai aspek pemasaran, aspek produksi, aspek pemodalan dan keuangan, dan aspek sumber daya manusia. Keempat, legalitas usaha. Pada bagian ini peserta dijelaskan mengenai bentuk-bentuk badan usaha baik formal maupun informal. Kelima, perencanaan usaha. Pada bagian ini peserta diperkenalkan sekaligus dilatih untuk mengenal peluang usaha, bagaimana menemukannya, bagaimana memilihnya, dan bagaimana memulainya.

Kegiatan pelatihan ini tidak hanya satu arah, tetapi terjadi dua arah dengan adanya sesi diskusi. Diskusi berlangsung setelah penyampaian materi dengan tertib dan terarah. Pada saat diskusi peserta berperan aktif melakukan tanya jawab terkait dengan permasalahan yang dihadapi 
oleh pelaku usaha masing-masing. Dampak dan manfaat dari kegiatan pengabdian kepada masyarakat dapat mengelola pembukuan keuangan usahanya dengan baik dan sistematis, sehingga dapat menghasilkan laporan keuangan seusai dengan standar yang berlaku, sehingga dapat membantu kelancaran bantuan dari pihak ketiga (misalnya Bank) yang pada akhirnya dapat membangun kekuatan UMKM sehingga tercapai kesejahteraan masyarakat Indonesia secara adil dan merata. Selain itu, penerapan pembukuan sederhana juga dapat menciptakan budaya disiplin di dalam perusahaan.

\section{SIMPULAN}

Berdasarkan hasil pelaksanaan kegiatan yang telah dilakukan, maka terdapat beberapa hal yang dapat disimpulkan dari kegiatan Pengabdian Pada Masyarakat ini, yaitu:

1. Pengetahuan dan pemahaman peserta pelaku usaha masih rendah terkait dengan semangat berwirausaha dan bagimana mengelola keuangan.

2. Pelatihan yang dilaksanakan mampu meningkatkan jiwa wirausaha dan motivasi para pelaku usaha dalam menjalankan usaha bisnisnya dengan baik dan optimal.

3. Hasil kegiatan Pelatihan pengabdian masyakarat ini menunjukkan bahwasannya perlu adanya pelatihan berwirausaha di setiap individu supaya jiwa berbisnis mereka semakin berkembang dan dapat menemukan hal baru yang lebih baik.

\section{SARAN}

Masyarakat bisa mendiskusikan lebih lanjut mengenai rencana selanjutnya mengenai bisnis yang mereka jalankan, agar masyarakat bisa mengolahnya dengan baik dan bisa dipatenkan sehingga bisa menjadi barang yang bernilai jual tinggi dan dapat bisa meningkatkan kualitas perekonomian masyarakat di Kelurahan Sukarame Bandar Lampung.

\section{UCAPAN TERIMA KASIH}

Ucapan Terima kasih tak terhingga kami sampaikan kepada Tim Pengabdian pada masyarakat Universitas Malahayati Bandar Lampung yang memberikan dukungan dan Bapak Lurah Sukarame beserta jajaran yang menyediakan fasilitas dan data yang kami butuhkan dalam melaksanakan kegiatan Pengabdian kepada Masyarakat ini.

\section{DAFTAR PUSTAKA}

Aryani et all. (2020). Pemasaran Bagi Pelaku Umkm Dan Masyarakat. Indonesian Journal Of Economic Community Development, 1(1), 35-41.

Farid Et All. (2020). Pelatihan Kewirausahaan Aplikatif Bagi Umkm. Seminar Nasional Hasil Pengabdian Kepada Masyarakat, 927-929.

Ismail Et All. (2020). Ibm Pelatihan Kewirausahaan Sebagai Upaya Menumbuhkan Jiwa Kewirausahaan Dan Menggali Ide Usaha Baru. Jurnal Pengabdian Nasional (Jpn) Indonesia, 1(1), 16-22. Https://Doi.Org/10.35870/Jpni.V1i1.3

Rumawas. (2018). Pelatihan Kewirausahaan Wanita Kaum Ibu Dan Pemuda Remaja Putri Jemaat Bukit Moria Malalayang. Jurnal Lppm Bidang Ekososbudkum, 4(2), 52-58.

Susita Et All. (2017). Pelatihan Kewirausahaan Bagi Pelaku Usaha Kecil Dan Binaan Koperasi Di Rumah Susun Sederhana Sewa (Rusunawa) Cipinang Besar Selatan. Jurnal Pemberdayaan Masyarakat Madani (Jpmm), 1(1), 58-72. Https://Doi.Org/10.21009/Jpmm.001.1.05 